Annals of Warsaw University of Life Sciences - SGGW

Land Reclamation No 45 (1), 2013: 41-48

(Ann. Warsaw Univ. of Life Sci. - SGGW, Land Reclam. 45 (1), 2013)

\title{
The analysis of some physical properties of drained peat-moorsh soil layers
}

RYSZARD OLESZCZUK ${ }^{1}$, MILENA TRUBA ${ }^{2}$

${ }^{1}$ Department of Environmental Improvement, Faculty of Civil and Environmental Engineering, Warsaw University of Life Science - SGGW

${ }^{2}$ Department of Grassland and Landscape Architecture, Siedlce University of Natural Sciences and Humanities

\begin{abstract}
The analysis of some physical properties of drained peat-moorsh soil layers. The paper presents the results of measurements of some physical properties for 14 drained fen peat-moorsh layers (degree of decomposition, bulk density, particle density, porosity and saturated moisture content). The soil samples were taken from north-east, central and east part of Poland. These areas were drained in order to use as a grassland and meadows. The article presents obtained data of selected physical properties from several drained peatlands in Poland and shows the comparison of established results with relevant data published in literature.
\end{abstract}

Key words: peat, drainage, moorsh, physical properties

\section{INTRODUCTION}

Most of lowland fen peat soils in Poland and Europe were drained in $19^{\text {th }}$ and $20^{\text {th }}$ century in order to use as grasslands, meadows and even sometimes as arable lands. The decreasing of groundwater level and moisture content were the main reasons to start unsuitable processes in these soils like mineralisation and degradation of basic physical and chemical properties. With drainage and aeration the organic soil matter goes to the irreversible moorsh forming process.
The basic physical soil properties are often describe by bulk density, particle density, porosity, saturated moisture content and in case of drained organic soils degree of decomposition. Values of bulk density as high as 0.2 to $0.4 \mathrm{Mg} \cdot \mathrm{m}^{-3}$ have been reported for fen peat for Central Europe (Okruszko 1993). Average values of particle density of peat soils is around $1.45 \mathrm{Mg} \cdot \mathrm{m}^{-3}$. Such parameter is rather weakly compared with bulk density. The highest values of particle density are observed for woody peats (Okruszko 1971, 1993). Peat soils are as one of the highest porous material. Total porosity of the undecomposed peat can reach even value of $97 \%$ and decrease for decompose and highly decomposed to level of $85-80 \%$. In the literature there are some published results of changing of basic physical properties due to drainage and mineralization processes (Okruszko 1971; Gawlik 1992; Piaścik and Łachacz 1997; Brandyk and Szatyłowicz 2002; Ilnicki and Zeitz 2003).

The aim of this paper is to analyse of some basic physical properties of several drained peat and moorsh soil layers from Poland and comparison of obtained data with other published results in the literature. 


\section{MATERIAL AND METHODS}

The peat-moorsh soils used in this study were taken from three following sites in Poland: north-east part Biebrza River valley - Podlaskie Voivodeship, central part - Mazovia Voivodeship and east part - Lubelskie Voivodeship. All of these peatlands areas were drainaged in $20^{\text {th }}$ century and used as a grasslands and meadows. The undisturbed soil samples were taken in four replication from each characteristic 14 layers in analysed 6 soil profiles. The presented data were shown according to peat group starting from alder peat to moss peat (Table 1). The values of bulk density and saturated moisture content were determined used by gravimetric method (Brandyk and Szatyłowicz 2002; Brandyk et al.

TABLE 1. Location of analysed peat-moorsh soil layers

\begin{tabular}{|c|c|c|c|c|c|c|}
\hline $\begin{array}{l}\text { No of } \\
\text { site }\end{array}$ & $\begin{array}{l}\text { Community } \\
\text { Voivodeship }\end{array}$ & $\begin{array}{c}\text { GPS } \\
\text { position }\end{array}$ & Name of site & $\begin{array}{c}\text { Depth } \\
\text { of sampling } \\
{[\mathrm{cm}]}\end{array}$ & Peat group & Peat species \\
\hline 1 & $\begin{array}{l}\text { Rajgród } \\
\text { Podlaskie }\end{array}$ & $\begin{array}{l}\mathrm{N}: 53^{\circ} 40^{\prime} 39.3^{\prime \prime} \\
\mathrm{E}: 22^{\circ} 37^{\prime} \\
39.5^{\prime \prime}\end{array}$ & Bełda & $30-40$ & \multirow{2}{*}{ alder } & $\begin{array}{l}\text { alder-swamp } \\
\text { forest }\end{array}$ \\
\hline 2 & $\begin{array}{c}\text { Góra Kalwaria } \\
\text { Mazowieckie }\end{array}$ & $\begin{array}{l}\mathrm{N}: 52^{\circ} 2^{\prime} 19.4^{\prime \prime} \\
\mathrm{E}: 21^{\circ} 6 \\
\end{array}$ & Solec & $35-45$ & & $\begin{array}{c}\text { alder-swamp } \\
\text { forest }\end{array}$ \\
\hline 3 & $\begin{array}{c}\text { Rajgród } \\
\text { Podlaskie }\end{array}$ & $\begin{array}{l}\mathrm{N}: 53^{\circ} 40^{\prime} 13.2^{\prime \prime} \\
\mathrm{E}: 22^{\circ} 34^{\prime} 31.7\end{array}$ & Miecze & $50-60$ & \multirow{3}{*}{ reed } & reed \\
\hline 4 & $\begin{array}{c}\text { Rajgród } \\
\text { Podlaskie }\end{array}$ & 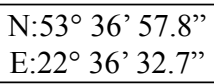 & Sołki & $50-60$ & & reed \\
\hline 5 & $\begin{array}{c}\text { Skórzec } \\
\text { Mazowieckie }\end{array}$ & $\begin{array}{l}\mathrm{N}: 52^{\circ} 5^{\prime} 0.2^{\prime \prime} \\
\mathrm{E}: 22^{\circ} 4^{\prime} 32.6^{\prime \prime}\end{array}$ & $\begin{array}{l}\text { Dąbrówka } \\
\text { Stany } \\
\text { Suchodół }\end{array}$ & $60-70$ & & reed \\
\hline 6 & $\begin{array}{c}\text { Warszawa } \\
\text { Mazowieckie }\end{array}$ & $\begin{array}{l}\mathrm{N}: 52^{\circ} 7^{\prime} \\
\mathrm{E}: 21.1^{\circ} 66^{\prime \prime} \\
49.1^{\prime \prime}\end{array}$ & Powsin & $30-45$ & \multirow{5}{*}{ sedge } & sedge-reed \\
\hline 7 & $\begin{array}{c}\text { Warszawa } \\
\text { Mazowieckie }\end{array}$ & $\begin{array}{l}\mathrm{N}: 52^{\circ} 7^{\prime} 21.8^{\prime \prime} \\
\mathrm{E}: 21^{\circ} 66^{\prime} 49.1^{\prime \prime}\end{array}$ & Powsin & $45-55$ & & sedge-reed \\
\hline 8 & $\begin{array}{c}\text { Serniki } \\
\text { Lubelskie }\end{array}$ & 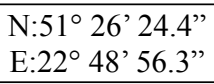 & Brzostówka & $45-55$ & & sedge-reed \\
\hline 9 & $\begin{array}{c}\text { Skórzec } \\
\text { Mazowieckie }\end{array}$ & $\begin{array}{l}\mathrm{N}: 52^{\circ} 4^{\prime} 48.0^{\prime \prime} \\
\mathrm{E}: 22^{\circ} 5 \\
\end{array}$ & $\begin{array}{l}\text { Dąbrówka } \\
\text { Stany } \\
\text { Zapulec }\end{array}$ & $45-55$ & & sedge-reed \\
\hline 10 & $\begin{array}{c}\text { Skórzec } \\
\text { Mazowieckie }\end{array}$ & $\begin{array}{l}\mathrm{N}: 52^{\circ} 5^{\prime} 0.2^{\prime \prime} \\
\mathrm{E}: 22^{\circ} \text { 4' } 32.6^{\prime \prime}\end{array}$ & $\begin{array}{l}\text { Dąbrówka } \\
\text { Stany } \\
\text { Suchodół }\end{array}$ & $45-55$ & & sedge \\
\hline 11 & $\begin{array}{l}\text { Grajewo } \\
\text { Podlaskie }\end{array}$ & $\begin{array}{l}\mathrm{N}: 53^{\circ} 37^{\prime} 59.1 " \\
\mathrm{E}: 22^{\circ} 34^{\prime} 56.1 "\end{array}$ & $\begin{array}{l}\text { Lamane } \\
\text { Grądy }\end{array}$ & $50-60$ & moss & sedge-moss \\
\hline 12 & $\begin{array}{c}\text { Serniki } \\
\text { Lubelskie }\end{array}$ & 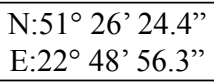 & Brzostówka & $15-25$ & \multirow{3}{*}{ moorsh } & humic moorsh \\
\hline 13 & $\begin{array}{c}\text { Skórzec } \\
\text { Mazowieckie }\end{array}$ & $\begin{array}{l}\mathrm{N}: 52^{\circ} 4 \\
\mathrm{E}: 22^{\circ} \\
5\end{array}$ & $\begin{array}{c}\text { Dąbrówka } \\
\text { Stany Zapulec }\end{array}$ & $20-30$ & & humic moorsh \\
\hline 14 & $\begin{array}{l}\text { Góra Kalwaria } \\
\text { Mazowieckie }\end{array}$ & $\begin{array}{l}\mathrm{N}: 52^{\circ} 2^{\prime} 19.4^{\prime \prime} \\
\mathrm{E}: 21^{\circ} 6 \\
\end{array}$ & Solec & $10-20$ & & humic moorsh \\
\hline
\end{tabular}


2003). The particle density of analysed peat and moorsh layers were done using picnometr method (Maciak and Liwski 1996). Based on bulk density and particle density the porosity of soil samples was calculated. The degree of decompositions, peat group and species and type of moorsh were estimated using microscopic method proposed by Okruszko (1971) and Maciak and Liwski (1996). The peat soil classification presented in Table 1 was prepared using Tołpa et al. (1967) proposition.

\section{RESULTS AND DISCUSSION}

The obtained results of analysed physical properties are presented in Table 2 .

The lowest degree of decomposition $(30 \%)$ was observed for reed and moss peats and the highest $(70 \%)$ for reed and sedge peats (Fig. 1). Generally the rising of degree of decomposition (the rate of degradation and mineralisation) causes the increasing of bulk density and decreasing of porosity and saturated moisture content. In case of moorsh

TABLE 2. Characteristics of some physical properties of analysed peat-moorsh soil layers

\begin{tabular}{|c|c|c|c|c|c|c|c|}
\hline \multirow[t]{2}{*}{$\begin{array}{l}\text { No } \\
\text { of } \\
\text { site }\end{array}$} & \multirow[t]{2}{*}{ Name of site } & $\begin{array}{l}\text { Depth of } \\
\text { sampling }\end{array}$ & Bulk density & $\begin{array}{l}\text { Particle } \\
\text { density }\end{array}$ & Porosity & $\begin{array}{c}\text { Saturated } \\
\text { volumetric } \\
\text { moisture } \\
\text { content }\end{array}$ & $\begin{array}{l}\text { Degree } \\
\text { of decom- } \\
\text { position }\end{array}$ \\
\hline & & {$[\mathrm{cm}]$} & {$\left[\mathrm{Mg} \cdot \mathrm{m}^{-3}\right]$} & {$\left[\mathrm{Mg} \cdot \mathrm{m}^{-3}\right]$} & {$[\%]$} & [vol. \%] & {$[\%]$} \\
\hline 1 & Bełda & $30-40$ & 0.30 & 1.83 & 83.73 & 82.77 & 50 \\
\hline 2 & Solec & $35-45$ & 0.25 & 1.59 & 81.91 & 81.91 & 65 \\
\hline 3 & Miecze & $50-60$ & 0.19 & 1.56 & 87.95 & 87.84 & 30 \\
\hline 4 & Sołki & $50-60$ & 0.14 & 1.52 & 90.83 & 90.92 & 35 \\
\hline 5 & $\begin{array}{l}\text { Dąbrówka } \\
\text { Stany } \\
\text { Suchodół }\end{array}$ & $60-70$ & 0.20 & 1.61 & 87.74 & 86.87 & 70 \\
\hline 6 & Powsin & $30-45$ & 0.22 & 1.70 & 87.35 & 87.13 & 35 \\
\hline 7 & Powsin & $45-55$ & 0.13 & 1.57 & 91.62 & 90.80 & 35 \\
\hline 8 & Brzostówka & $45-55$ & 0.12 & 1.51 & 91.74 & 92.31 & 40 \\
\hline 9 & $\begin{array}{c}\text { Dąbrówka } \\
\text { Stany } \\
\text { Zapulec }\end{array}$ & $45-55$ & 0.17 & 1.60 & 89.49 & 88.05 & 50 \\
\hline 10 & $\begin{array}{l}\text { Dąbrówka } \\
\text { Stany } \\
\text { Suchodół }\end{array}$ & $45-55$ & 0.22 & 1.64 & 86.47 & 84.05 & 70 \\
\hline 11 & $\begin{array}{l}\text { Łamane } \\
\text { Grądy }\end{array}$ & $50-60$ & 0.18 & 1.64 & 88.97 & 88.68 & 30 \\
\hline 12 & Brzostówka & $15-25$ & 0.15 & 1.50 & 90.07 & 89.41 & $\mathrm{Z}_{2}{ }^{\mathrm{a}}$ \\
\hline 13 & $\begin{array}{l}\text { Dąbrówka } \\
\text { Stany } \\
\text { Zapulec }\end{array}$ & $20-30$ & 0.20 & 1.68 & 88.15 & 86.02 & $Z_{2}$ \\
\hline 14 & Solec & $10-20$ & 0.40 & 1.78 & 77.56 & 75.96 & $Z_{2}$ \\
\hline
\end{tabular}

${ }^{\mathrm{a}} \mathrm{Z}_{2}$ - humic moorsh. 


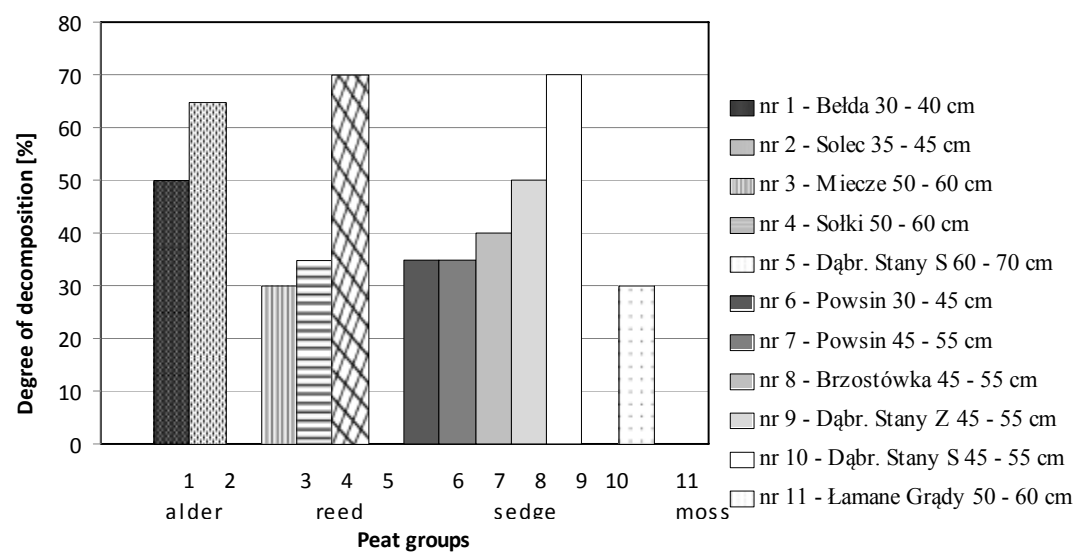

FIGURE 1. The degree of decomposition for analysed fen peat groups

layer $\left(Z_{2}\right.$ humic moorsh) there is large gape between basic physical properties: the highest values of bulk density and particle density was observed for Solec site $(10-20 \mathrm{~cm})$ and the lowest values of these parameters for Brzostówka site $(15-25 \mathrm{~cm})$.

The relationship between bulk density and particle density was presented on Figure 2. The average values of bulk density $0.1-0.25 \mathrm{Mg} \cdot \mathrm{m}^{-3}$ corespondent to values of bulk density in the range $1.5-1.7 \mathrm{Mg} \cdot \mathrm{m}^{-3}$. The highest values of bulk density $\left(0.3-0.4 \mathrm{Mg} \cdot \mathrm{m}^{-3}\right)$ and particle density (around $1.8 \mathrm{Mg} \cdot \mathrm{m}^{-3}$ ) were observed for moorsh layers.

The measured in the laboratory saturated moisture content and calculated porosity values (using bulk density and particle density) were presented on Figure 3 . The values of these parameters should be very similar (porosity equals saturation moisture content, no air in saturation soil samples). The lowest values of considered parameters are for moorsh and alder peats layers (Fig. 3).

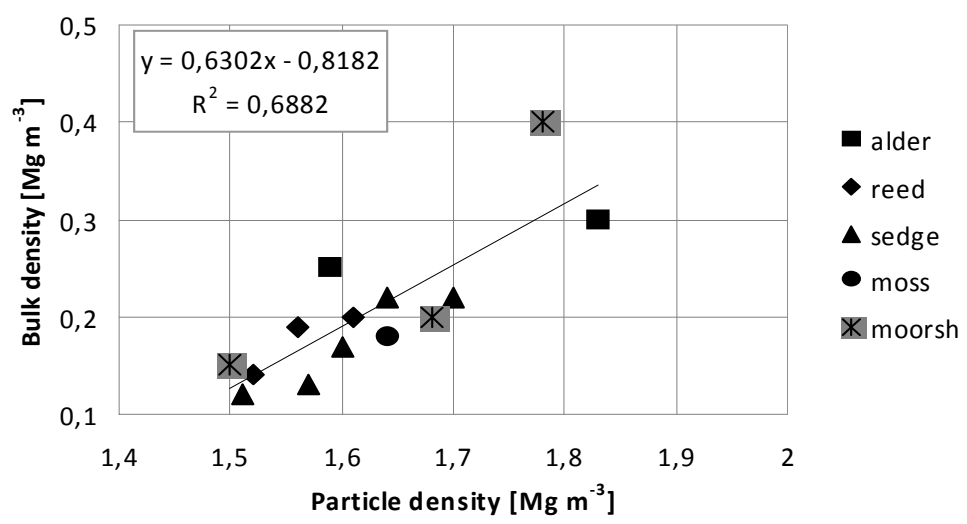

FIGURE 2. The relationship between bulk density and particle density for analysed soil layers 


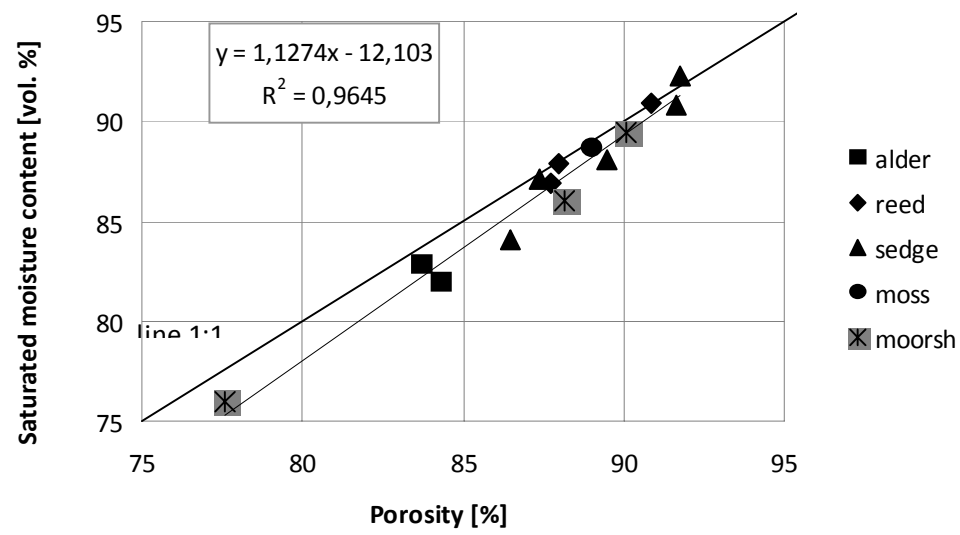

FIGURE 3. The comparison between saturated moisture content and porosity for considered soil layers

The bulk density has large influence on porosity and moisture content values. High values of bulk density causes the decreasing of porosity (moisture content). In case of analysed peat and moorsh soil layers the strong linear relationship between these parameters is presented (Fig. 4). Increasing the bulk density values from $0.1 \mathrm{Mg} \cdot \mathrm{m}^{-3}$ to $0.4 \mathrm{Mg} \cdot \mathrm{m}^{-3}$ causes decreasing the porosity from around 92 to around $77 \%$.

The next physical parameter - degree of decomposition decreasing also the saturated moisture content (porosity) values of all analysed peat layers (Fig. 5).

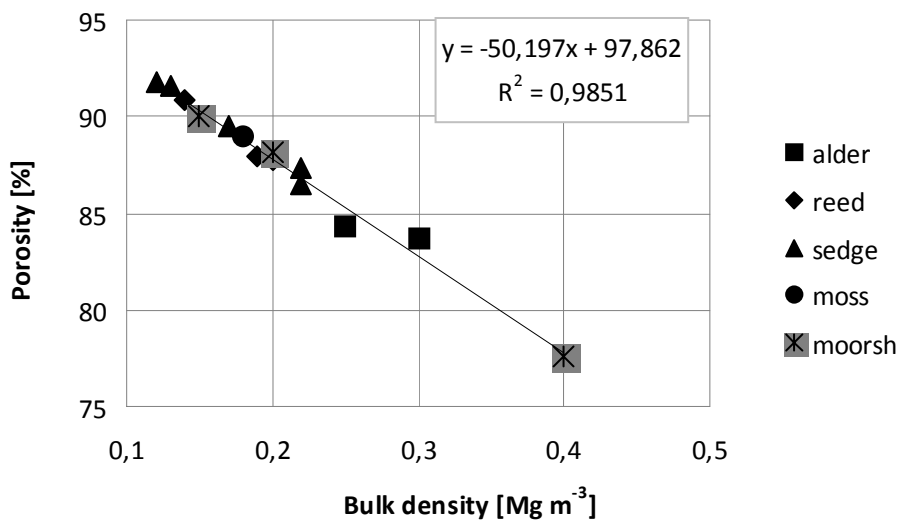

FIGURE 4. The relationships between porosity and bulk density for peat-moorsh layers
The comparison of obtained data (porosity and bulk density) with relevant results presented in literature was presented on Figure 6. The similar and very closed to the author's relationship are the linear equations proposed by Zawadzki (1970) and Okruszko (1971).

The comparison of porosity and degree of decomposition were presented on Figure 7. For low degree of decomposition (low rate of mineralization and moorshing process) the values of porosity were very similar with increasing of degree of decomposition, the values of 


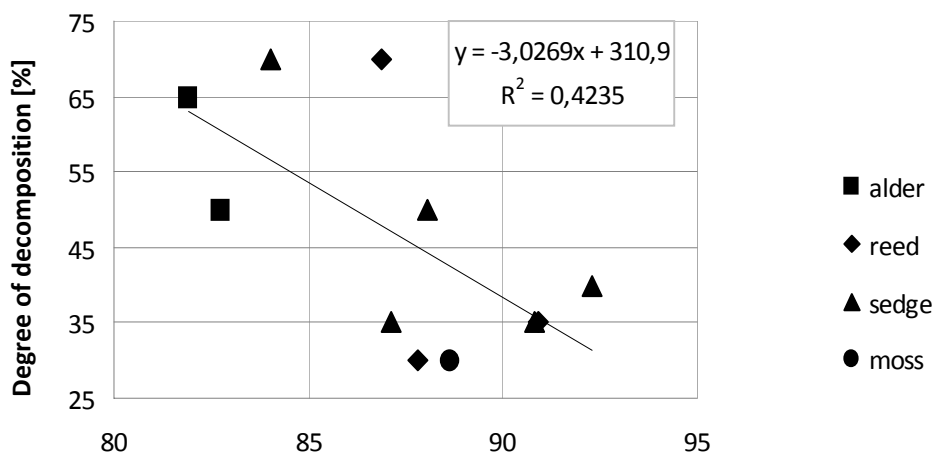

Saturated moisture content [vol. \%]

FIGURE 5. The characteristic of degree of decomposition and saturated moisture content for analysed soil layers

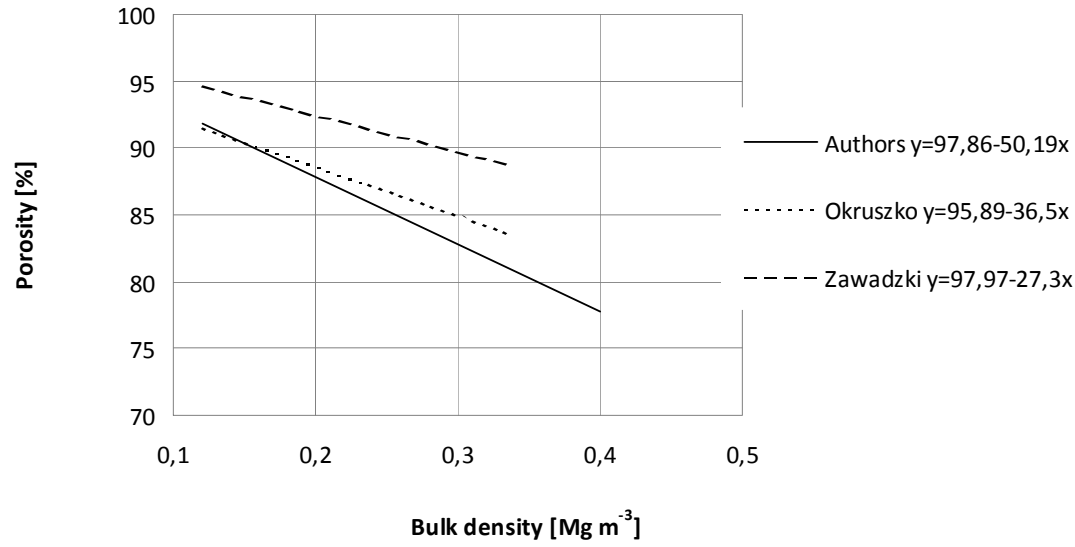

FIGURE 6 . The comparison of relationships between porosity and bulk density values

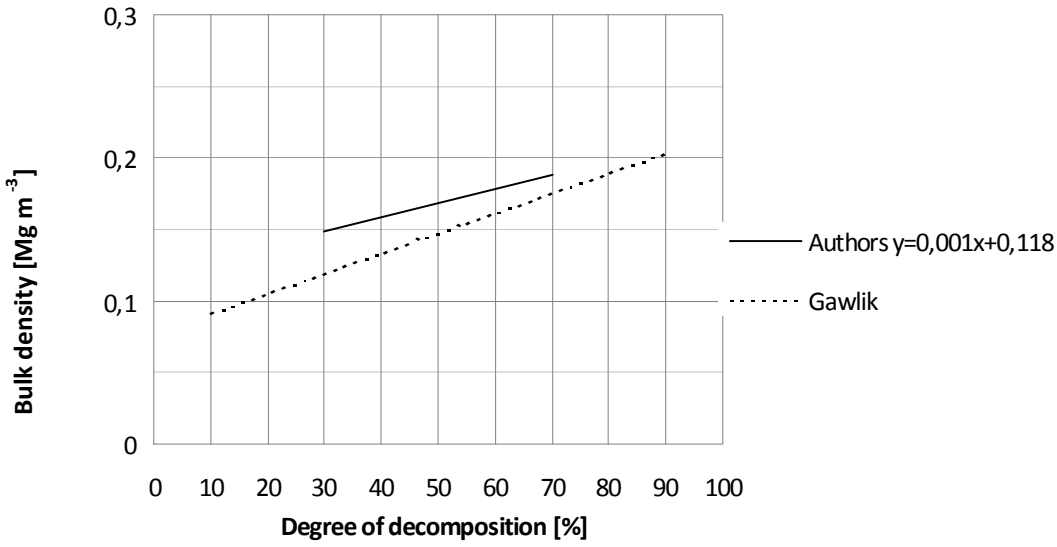

FIGURE 7. The comparison of relationships between porosity and degree of decompositions 
porosity were less than values of this parameter proposed by Gawlik (1992).

The very closed data are presented in case of bulk density and degree of decomposition proposed by present research and results presented by Gawlik (1992). The difference between measured data and presented by Gawlik (1992) are at the level 5\% (Fig. 8). ty was observed. Increasing the bulk density values from 0.1 to $0.4 \mathrm{Mg} \cdot \mathrm{m}^{-3}$ causes decreasing the porosity from around 92 to around $77 \%$.

4. The performed research of selected physical properties of drained peat-moorsh soil layers are similar to relevant data published in literature.

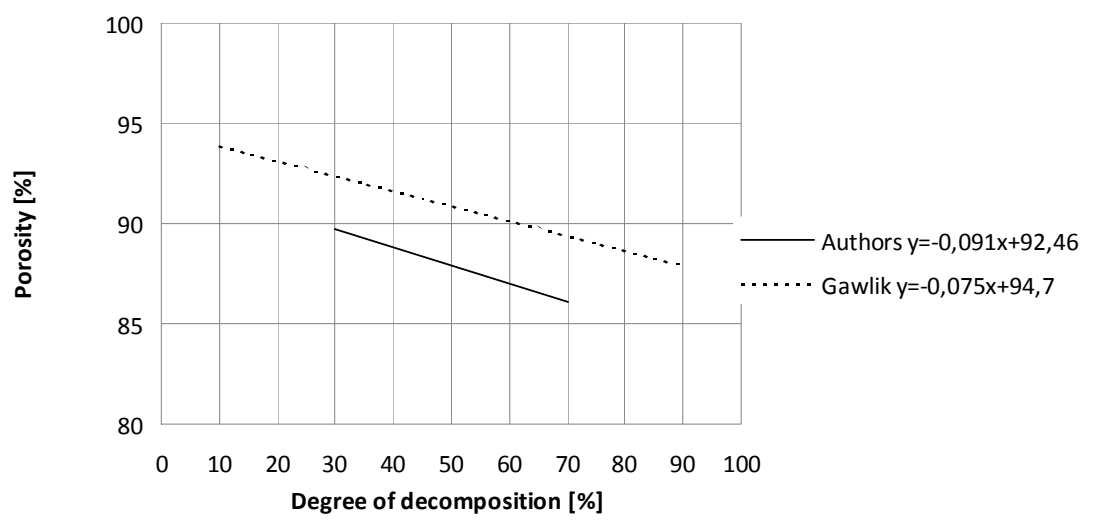

FIGURE 8 . The comparison of porosity and degree of decomposition for obtained data and published in the literature

\section{CONCLUSIONS}

Based on performed research the following conclusion can be proposed:

1. The degree of decomposition of drained peat soils plays important role on some physical properties: porosity (saturated moisture content) and bulk density.

2. The average values of bulk density 0.1-0.25 Mg. $\mathrm{m}^{-3}$ corespondent to values of bulk density in the range $1.5-1.7 \mathrm{Mg} \cdot \mathrm{m}^{-3}$. The highest values of bulk density $\left(0.3-0.4 \mathrm{Mg} \cdot \mathrm{m}^{-3}\right)$ and particle density (around $1.8 \mathrm{Mg} \cdot \mathrm{m}^{-3}$ ) were observed for moorsh layers.

3. In case of analysed peat and moorsh soil layers the strong linear relationship between porosity and bulk densi-

\section{REFERENCES}

BRANDYK T., SZATYŁOWICZ J. 2002: Właściwości fizyczne torfu. [Physical properties of peat] In: P. Ilnicki (ed.). Torfowiska $i$ torf [Peatlands and peat]. Wyd. Akademii Rolniczej im. Augusta Cieszkowskiego, Poznań, 408-426.

BRANDYK T., SZATYŁOWICZ J., OLESZCZUK R., GNATOWSKI T. 2003: Water - related physical attributes of organic soils. In: L.-E. Parent, P. Ilnicki (eds.). Ogranic soils and peat materials for sustainable agriculture. CRC Press and IPS, Boca Raton, Florida, 33-67.

GAWLIK J. 1992: Wptyw stopnia rozktadu torfu i stanu jego zagęszczenia na właściwości wodno-retencyjne utworów torfowych [The influence of degree of decomposition and density on water-retention of peat soils]. IMUZ, Lublin - Falenty, 86. 
ILNICKI P., ZEITZ J. 2003: Irreversible loss of organic soils functions after reclamation. In: L.-E. Parent, P. Ilnicki (eds.) Ogranic soils and peat materials for sustainable agriculture. CRC Press and IPS, Boca Raton, Florida, 15-32.

MACIAK F., LIWSKI S. 1996: Ćwiczenia $z$ torfoznawstwa [Peatlands guide-book]. Wydawnictwo SGGW, Warszawa, 25-26.

OKRUSZKO H. 1971: Określenie ciężaru właściwego gleb hydrogenicznych na podstawie zawartości $\mathrm{w}$ nich części mineralnych [Determination of specific gravity of hydrogenic soils on the basis of their mineral particles content]. Wiadomości IMUZ X,1, 47-54 [Engl. summ.].

OKRUSZKO H. 1993: Transformation of fen - peat under the impact of draining. Zeszyty Problemowe Postępów Nauk Rolniczych 406, 3-73.

PIAŚCIK H., ŁACHACZ A. 1997: The influence of dewatering and reclamation on water retention of peat soils in the sandy outwash landscape. Pol. J. Soil Sci. 30, 2, 7-14.

TOŁPA S., JASNOWSKI M., PAŁCZYŃSKI A. 1967: System der genetischen Klassifizierung der Torfe Mitteleuropas [The genetic classification of peat soil in the Middle Europe]. Zeszyty Problemowe Podstępów Nauk Rolniczych 76, 9-99.

ZAWADZKI S. 1970: Relationship between the content of organic matter and physical properties of hydrogenic soils. Pol. J. Soil Sci. 3, 1, 3-9.
Streszczenie: Analiza wybranych właściwości fizycznych odwodnionych warstw gleb torfowo-murszowych. Artykuł prezentuje wyniki pomiarów wybranych właściwości fizycznych dla 14 warstw odwodnionych dolinowych gleb torfowo-murszowych (stopień rozkładu, gęstość objętościowa gleby, gęstość fazy stałej, porowatość i wilgotność przy stanie pełnego nasycenia). Próbki glebowe pobrano w północno-wschodniej, centralnej i wschodniej części Polski. Tereny te odwodniono w celu rolniczego ich użytkowania jako użytki zielone i pastwiska. Praca przedstawia wyniki wybranych właściwości fizycznych dla analizowanych warstw glebowych i dokonuje porównania $\mathrm{z}$ wynikami podobnych badań opublikowanych w literaturze.

Słowa kluczowe: torf, mursz, właściwości fizyczne MS. received 28 June 2013

\section{Authors' addresses:}

Ryszard Oleszczuk

Katedra Kształtowania Środowiska

Wydział Budownictwa i Inżynierii Środowiska

SGGW

ul. Nowoursynowska 159

02-776 Warszawa, Poland

e-mail: ryszard_oleszczuk@sggw.pl

Milena Truba

Katedra Łąkarstwa i Kształtowania Terenów

Zieleni

Wydział Przyrodniczy

Uniwersytet Przyrodniczo-Humanistyczny

w Siedlcach

ul. Bolesława Prusa 14

08-110 Siedlce, Poland

e-mail: milena.truba@gmail.com 